\title{
Identification of geospatial variability of fluoride contamination in ground water of M athura District, Uttar Pradesh, India
}

\author{
K. S. Rawat*1 ${ }^{1}$ A. K. M ishra ${ }^{1}$ and V. K. Sehgal ${ }^{2}$
}

${ }^{1}$ Soil and Water Conservation Engineering, Water Technology Centre, Indian Agricultural Research Institute, New Delhi -110012, INDIA

${ }^{2}$ Division of Agricultural Physics, Indian Agricultural Research Institute, New Delhi- 110012, INDIA

*Corresponding author. E-mail: ks_rawat2002@yahoo.com

\begin{abstract}
Groundwater is one of the major sources of water in arid and semi-arid regions. Groundwater quality data and its spatial distribution are important for the purpose of planning and management. Geo-statistical methods are one of the most advanced techniques for interpolation of groundwater quality. In this study, kriging methods were used for predicting the spatial distribution of fluoride content in groundwater. Data were collected from 13 wells in Mathura district (Uttar Pradesh, India). After normalization of data, semivariogram was drawn, for selecting suitable model for fitness on experimental semivariogram, less residual sum of squares (RSS) value was used. Then fluoride endemic areas of the Mathura District (study area) were identified from developed semivariogram model and Geospatial variability (high and low fluoride containing areas) map was generated with the help of Geographic Information System. In the analysis, spatial distribution characteristics and variation of fluoride concentration in shallow groundwater found to be 3.4 and $4.6 \mathrm{mg} / \mathrm{l}$ at Sahar, Shahpur were higher than the standard limits $(1.5 \mathrm{mg} / \mathrm{l})$ of drinking water and shows remarkable spatial variability.
\end{abstract}

Keywords: Geo-statistical methods, Ground water quality, Interpolation, Spatial distribution

\section{INTRODUCTION}

Water is vital to all living creatures. Today's civilized society required a good knowledge of the existences, replenishment and recovery of potable groundwater because it will assume special significance in qualitydeteriorated region due to scarce presence of surfaces water. Not only so, negative climatic condition like low rainfall during quick occurrence of dry spells, high evaporation due to high temperature and due to soil composition quality etc (Todd, 1980).

This research has been carried out with the aim of testing the performance of spatial interpolation techniques for mapping of Fluoride in Groundwater over the Mathura District, U.P. (Hem, 1989 and Ekhtesasi, 2004). 2.5 million People living in 8700 villages in India suffer the problem of excess fluoride intake (Handa, 1975; 1988; Nawlakhe and Bulusu, 1989). Karthikeyan and Shunmugasundarraj, (2000) studied the in-situ fluoride dependence on water quality in the Krishnagiri block of TamilNadu in South India using Isopleth mapping. Dhiman and Keshari, (2001) have used GIS to quantify the spatial geologic data and statistical analysis to determine the degree of fluoride contamination in groundwater. Karro et al. (2006) examined the content and spatial distribution of fluoride in drinking water using SPADNS method in Estonian territory. Fordyce (2007) reported that fluoride is a powerful calcium-seeking element and can interfere with the calcified structure of bones and teeth in the human body at higher concentrations causing dental or skeletal fluorosis.

Several studies have been made to analize the accuracy of interpolation methods for spatially predicting soil and water properties like Hounslow (1995); Robinson and Metternicht (2006). Safari (2002) utilized kriging method for estimating spatial prediction of groundwater in Chamchamal plain area situated in west of Iran. Results of this method tell that when suitable method of geostatistics to estimate one variable depends on variables type and regional factors which affect these and any selected method for given region cannot be generalized to others (Meer, 1993). Geo-statistics method was used for studying spatial variability of groundwater quality in Balarood plain area (Nazari et al., 2006). The result found showed that spherical model is the best model for fitting on experimental variograme of $\mathrm{F}^{-}$variable. Istock and Cooper (1998) used kriging method to estimate heavy metals. They conclude that the kriging method is the best estimation for spatial prediction of lead. Dagostino et al. (1998) used kriging and cokriging methods for spatial and temporal variability of nitrate in groundwater. The results obtained by them showed that kriging method has resulted in increasing accuracy to 
estimate $\mathrm{F}^{-}$concentration. Ahmed, 2002 demonstrated accuracy of kriging method to prediction of TDS in groundwater. Gaus et al. (2003) studied pollution of groundwater in Bangladesh in view of heavy metal. Disjunctive kriging method was used by them to estimate arsenic concentration and to prepare risk map. As per their results showed that 35 million people are exposed in high concentration of Arsenic (50 ppm) and 50 million people are exposed in $10 \mathrm{ppm}$. Finke et al. (2004) by using simple kriging method for estimate water surface changes in Netherlands found that the method is suitable one for mapping of water surface. Barca and Passarella (2008) used disjunctive kriging and simulation methods for preparing nitrate risk map in $10,50(\mathrm{mg} / \mathrm{l})$ thresholds, in Modena plain of Italy. The present study was therefore, carried out with the aim of using spatial interpolation techniques for mapping of Fluoride $\left(\mathrm{F}^{-}\right)$content in groundwater quality for Mathura district (Uttar Pradesh), India.

In Mathura district, water logging and salinity in ground water have become a serious problem. A large quantity of ground water is of no use due to its high salinity. Most of the ground water in Mathura district of Uttar Pradesh (U.P) occurs under unconfined and semiconfined condition whereas near surface it is found under water table condition. Very high $\mathrm{F}^{-}$value of 3.4 and 4.6 $\mathrm{mg} / \mathrm{l}$ are found in the well water of Sahar and Shahpur. In this paper, an attempt has been made to study the Fluoride quality of ground water collected from fixed 13 dug wells in Mathura district (U.P) and its spatial distribution.

\section{MATERIALS AND METHODS}

Topography of the study area: Mathura district is bordered by Haryana state in the north and by Rajasthan state in the west. It is between lat $27^{\circ} 14^{\prime}$ to $27^{\circ} 58^{\prime}$ North and long $77^{\circ} 17^{\prime}$ to $78^{\circ} 12^{\prime}$ East in the toposheet No 54E and 54I of Survey of India covering a total of $3797 \mathrm{sq} . \mathrm{km}$. (Fig.1). Yamuna River is the major perennial river in the area which enters north of Mathura district near Shahpur and leaves it in SSE direction near Akos. Yamuna river divides Mathura district in two physiographic units Yamuna and trans Yamuna. Agra canal is another surface water resource used in the area under study.

$\mathrm{H}$ ydrogeology of the area: Ground water occurs under unconfined and semi-confined conditions. The depth to water table varies from $1.8 \mathrm{mbgl}$ (meter below ground level) to $17.47 \mathrm{mbgl}$ during pre-monsoon period and from $1.39 \mathrm{mbgl}$ to $17.18 \mathrm{mbgl}$ during post monsoon. The general direction of flow of ground water is from NNW (North, North-West) to SSE (South South-East). The influent Seepage from canal as well as its distributaries has modified the general direction of ground water flow.

Assessment of spatial correlation in hydrochemical variables is an important tool in the analysis of groundwater chemistry. This paper investigates the spatial correlation of the Mathura ground water data sets using Kriging method (Franco et al., 2009; Goovaerts, 1997 and Goovaerts et al., 2005). Spatial assessment of groundwater chemistry is important for revealing the correlation between location and the hydrochemical variables in the present study. The integrated land and water information system 3.3 is a PC-based GIS and Remote Sensing software which was used in the present study to determine kriged map (Fig. 2). Examples are given of the type of semivariogram found in the study area, while Kriged maps illustrate the spatial relationships found. The semivariogram analysis of the geo-statistical assessment revealed that for the dataset, the spatial correlation has a relatively short range therefore the sill value is difficult to analyze because of a spatial trend in the data, leading to an increase of the semi-variance almost immediately after the sill has been reached (Goovaerts, 1997 and Goovaerts et al., 2005).

Thirteen water samples were collected from phreatic aquifer in clean pre-rinsed100 $\mathrm{ml}$ plastic (polyethylene) bottles. 2-3 drops of toluene were added in each bottle to prevent microbial growth. Samples were analyzed for Fluoride $\left(\mathrm{F}^{-}\right)$anions.

Groundwater depth and quality data acquisition: The data related to groundwater were acquired from field woke for the year 2007 covering 13 groundwater sampling points. 13 ground water samples from phreatic aquifer were collected in clean polyethylene bottles from fixed wells established in Mathura district, U.P. (Fig. 1). Collected samples were analyzed (as per procedure laid down in APHA (1996)) in the laboratory to measure the concentration of $\mathrm{F}^{-}$parameter. The water quality parameter along with the locations of the tube wells were used for spatial data analysis (SDA), development of semivariogram models and generation of spatial variability map with the help of GIS (Srivastava et al., 1997; Anbazhagan and Nair, 2004).

Geostatistical approach in development of spatial variability models: Kriging is a general term describing a geostatistical approach for interpolation at unsampled locations. This method provides less bias in predictions, so known as best linear unbiased estimator (BLUE). This is because the interpolated or kriged values are computed fromequations that minimize the variance of the estimated value. Another advantage of kriging is that it presents the possibility of estimation of the interpolation error of the values of the regionalized variable where there are no initial measurements. The spatial dependence is quantified using semi-variogram (Stefanoni and Hernandez, 2006). The experimental semi-variogram is a graphical representation of the mean square variability between two neighboring points of distance $\mathrm{h}$ as shown in Eq. (1). 
$\gamma(h)=\frac{1}{2 N(h)} \sum_{i=1}^{N(h)}\left[z\left(x_{i}+h\right)-z\left(x_{i}\right)\right]^{2}$

Where $\gamma(\mathrm{h})$ is the semi-variogram expressed as a function of the magnitude of the lag distance or separation vector $\mathrm{h}, \mathrm{N}(\mathrm{h})$ is the number of observation pairs separated by distance $h$ and $Z\left(X_{i}\right)$ is the random variable at location $X_{i}$. The experimental variogram, $\gamma(h)$ is fitted in theoretical model such as Spherical, Exponential, Linear or Gaussian to determine three parameter, such as the nugget $\left(\mathrm{c}_{0}\right)$, the sill (c) and the range $\left(\mathrm{A}_{0}\right)$. These models are defined as follows (Goovaerts et al., 1999).

Spherical model:

$$
\begin{array}{ll}
\gamma(\mathrm{h})=\mathrm{c}_{0}+\left[1.5\left(\frac{\mathrm{h}}{\mathrm{A}_{0}}\right)-0.5\left(\frac{\mathrm{h}}{\mathrm{A}_{0}}\right)^{3}\right] & \mathrm{h} \leq \mathrm{A}_{0} \\
\gamma(\mathrm{h})=\mathrm{c}_{0}+\mathrm{c}, & \mathrm{h}>\mathrm{A}_{0}
\end{array}
$$

Exponential model:

$\gamma(h)=c 0+c\left[1-\exp \left(-3 \frac{h}{A_{0}}\right)\right]$

Gaussian model:

$\gamma(h)=c 0+c\left[1-\exp \left[-\left(\frac{3 h}{A_{0}}\right)^{2}\right]\right]$

L inear model:

$$
\gamma(h)=c 0+h\left(\frac{c}{A_{0}}\right)
$$

Interpretation of the resulting semivariograms and K riging maps semivariograms: The semivariograms parameter nugget, sill and range for the data sets are summarized in Table 3 and depicted through the graphs (Fig. 3). In general the semivariograms can be modeled with a spherical semi-variogram up to lag distances of $40000 \mathrm{~m}$. At larger distances the trend effect starts dominantly. And up to medium distance, low value of correlation effect was found. There was a substantial nugget affect indicating large variability at very short distances and this may be attributed to both aquifer characteristics and errors in the chemical analysis (Hong and Chon, 1999).

Inter pretation of K riging maps: Fig. 2 shows the distribution according to the average chemical composition of $\mathrm{F}^{-}$for the year 2007. Most part of study area falls in the region where the average values of $\mathrm{F}^{-}$is $3 \mathrm{mg} / \mathrm{l}$. Boundary of study area at right side in Kriging map shows normal values $(0.977 \mathrm{mg} / \mathrm{l})$ of $\mathrm{F}$ -

\section{RESULTS AND DISCUSSION}

High F, values (Fig. 2) at Kosi Nala, Sahar, Adampur, Jacchoda and Chaumuhan with a maximum of $4.6 \mathrm{mg} / \mathrm{l}$ at Shahpur are harmful for potable purpose and may cause health hazards. Since F>1.5 mg/l (Tables 1,2) in water is not suitable for drinking purpose (BIS, 1991; WHO, 1993). The proposed methodology requires the definition of factorial variables, to identify the physico-chemical processes that affect groundwater, for subsequent analysis of the spatial distribution of these variables using geo-statistical estimation techniques. The geostatistical techniques constitute a useful tool for the study of spatial variability in groundwater chemistry (Sawyer and Mcarty, 1967).

Elevated of fluoride status in ground waters leaching from soils or weathering, rock, Deposition of atmospheric volcanic particles, Runoff and infiltration of chemical fertilizers from agricultural areas, Septic and sewage treatment system discharges in communities with fluoridated water supplies, Liquid waste from industrial sources, sandstone and mudstone aquifer system on Mathura District are largely a result of base-exchange softening. It is evident that this process may be responsible for elevated fluoride levels in groundwater around study area (Mathura District, U.P.).

From the above results it is clear that the ground water from Sahar and Shahpur parts of study area has quality problems like, high fluoride content 3.4 and $4.6 \mathrm{mg} / 1$ (Table 1). People have to be advised to avoid these sources, as use of these may result in dental fluorosis. To avoid cases of fluorosis like, at low concentrations fluoride can reduce the risk of dental cavities, Higher amounts of fluoride can cause dental fluorosis, Even higher intakes of fluoride taken over a long period of time can result in changes to bone, a condition known as skeletal fluorosis, causes joint pain and be hazardous for health (BIS, 1991), restriction of mobility and possibly increase the risk of some bone fractures from this study area of Mathura District. People have to be advised to use surface water especially river water supply schemes as far as possible. Serious attempts are needed to develop community based de-fluoridation systems as a permanent solution to the problem.

It is recommended that, the brackish water associated with salty taste should be blended with fresh water so that unused water could be brought in to use for potable purposes. Excessive use of fertilizer both phosphatic and potassic should be avoided in agricultural activity. Most important is that area where ground water associated with high $\mathrm{F}^{-}$value should not be used for potable purposes or suitable de-fluoridization technique such as Nalgonda technique, blending with low FÉ water ion exchange and chemical treatment etc. should be adopted to keep $\mathrm{F}^{-}$concentration of water samples within limits.

\section{Conclusion}

The study has demonstrated the utility of GIS technology along with laboratory analysis in evaluation and Geospatial variability mapping of fluoride containing in 


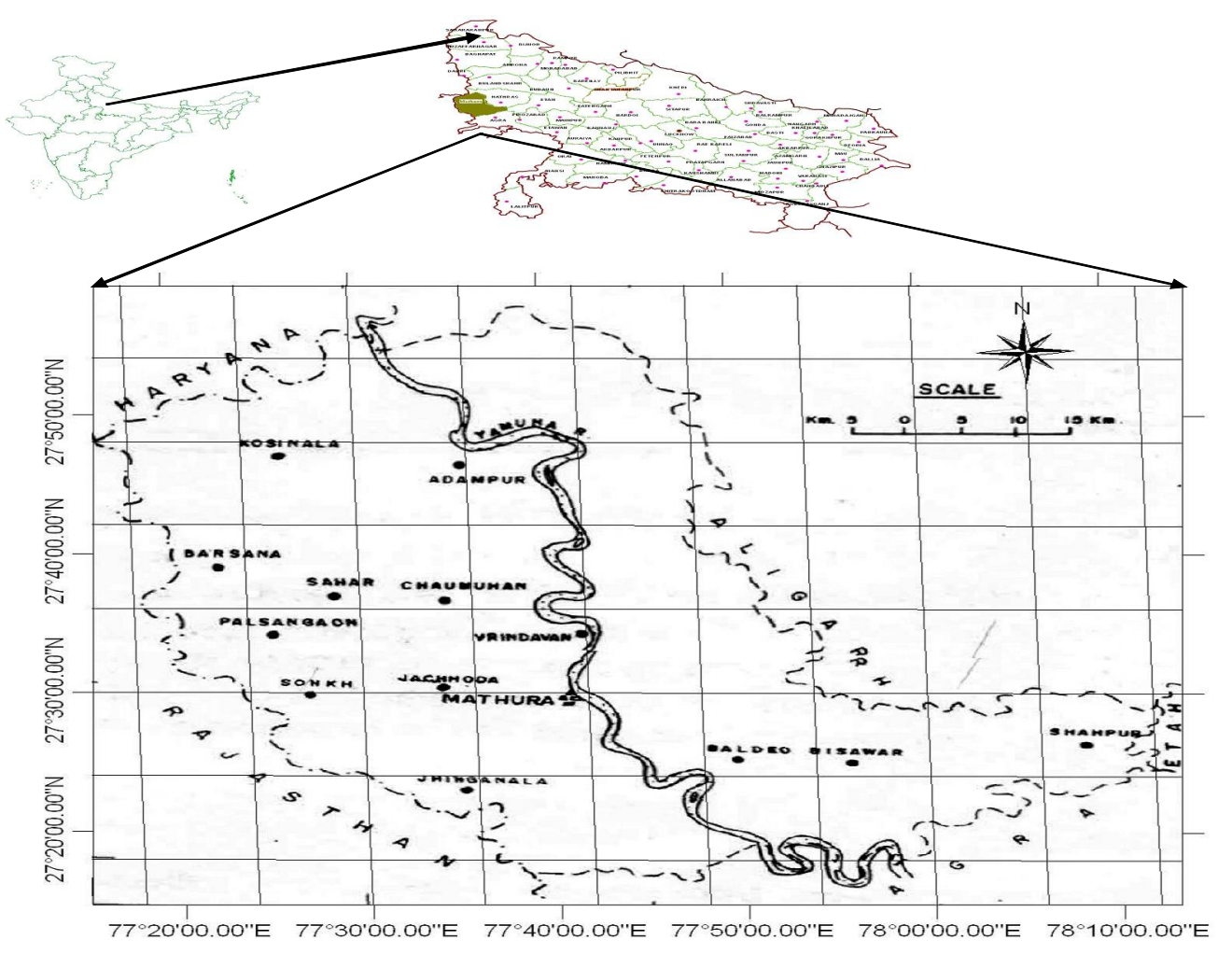

Fig. 1. Location map of $M$ athura district of $U$ ttar Pradesh.

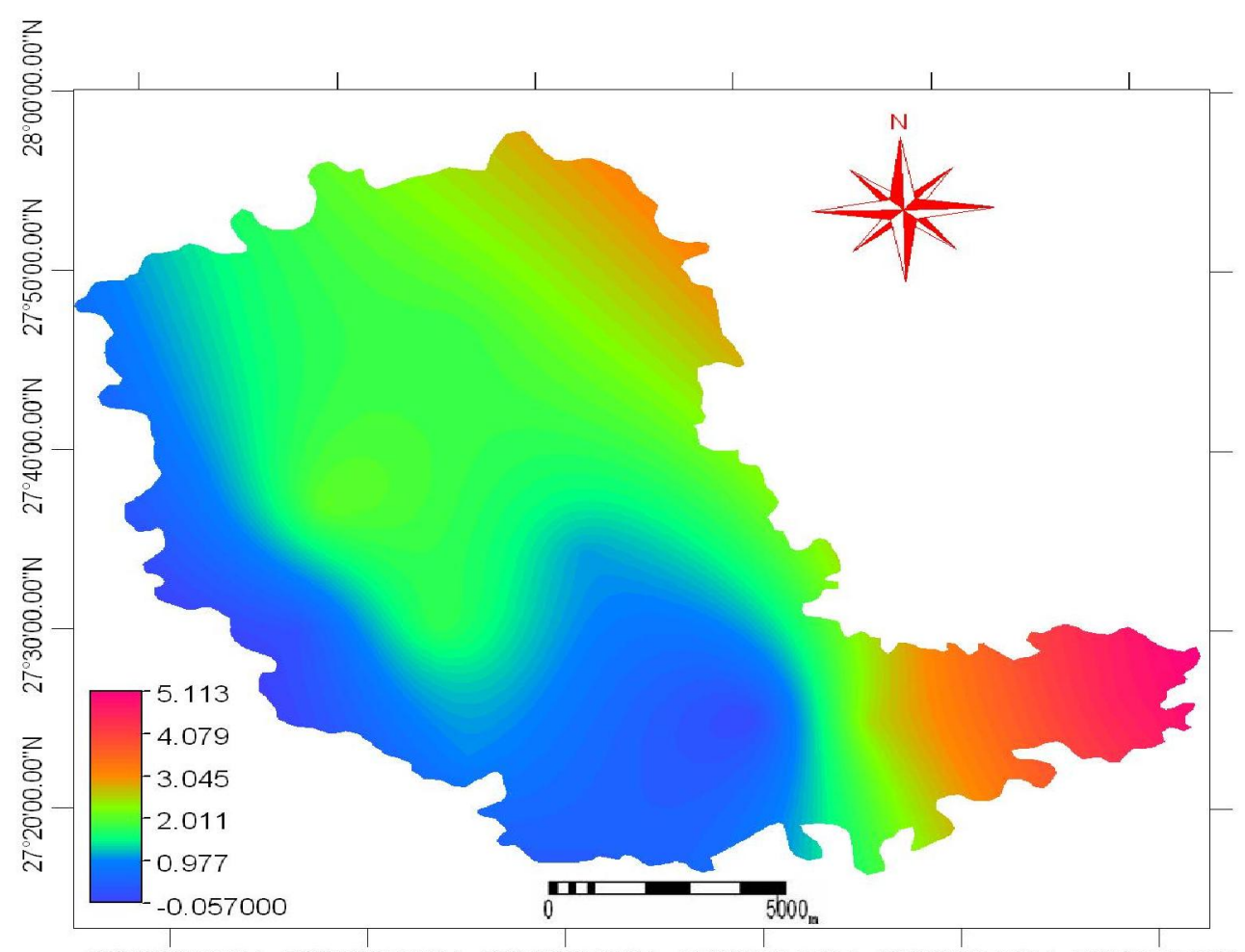

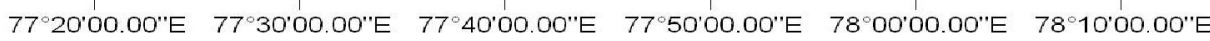

Fig. 2. Spatial variability map of fluoride (F-) (mg/l) over M athura district of $U$ ttar Pradesh.

groundwater quality in Mathura (U.P., India) for year 2007. About $70 \%$ of the area under study comes under moderately polluted (fluoride affected) to severely polluted rang 2.0 to 5.1 (according Fig. 2) revealed by the GIS tool.
The below part of the river (Yamuna) locations are only safe rang ( 0.06 to 0.97 ) as showed Fig. 2 and can be use for drinking purpose in the study area. The spatial distribution maps generated for fluoride (physicochemical parameter) 




Fig. 3. Semi variogram of fluoride (F-) for 2007 data.

Table 1. Fluoride concentration in shallow ground water samples of Mathura district of Uttar Pradesh.

\begin{tabular}{llcc}
\hline & Location & Sample no & $\mathrm{F}(\mathrm{mg} / \mathrm{l})$ \\
\hline 1 & Brsawar & 4 & 1.5 \\
2 & Sahar & 5 & 3.4 \\
3 & Shahpur & 5 & 4.6 \\
4 & Vrindavan & 3 & 1.1 \\
5 & Baldeo & 1 & 0.9 \\
6 & Adampur & 1 & 1.8 \\
7 & Kosi Nala & 1 & 1.6 \\
8 & Sonkh & 7 & 2.2 \\
9 & Chaumuhan & 8 & 1.8 \\
10 & Palsonga & 1 & 1.0 \\
11 & Jhinga Nala & 3 & 1.6 \\
12 & Jacchoda & 4 & 1.8 \\
13 & Barsana & 6 & 0.9 \\
\hline
\end{tabular}

Table 2. Groundwater quality standards for various chemical components.

\begin{tabular}{lcc}
\hline Chemical & Tolerance limit & R ejection limit \\
\hline $\mathrm{Cl}$ & 200 & 1000 \\
$\mathrm{~F}$ & 01.5 & 1.500 \\
$\mathrm{SO}_{4}$ & 200 & 0400 \\
$\mathrm{Ph}$ & $7-8.5$ & $6.5-9.2$ \\
$\mathrm{EC}$ & $10^{-3}$ & -- \\
\hline
\end{tabular}

Source: Fluoride 2000. 33(3), 121-127, Research Report-121, India. Except $\mathrm{pH}$ all parameters concentration are in $\mathrm{mg} / \mathrm{l}$.

using GIS techniques could be useful for planners and decision makers for initiating groundwater quality development in the area. Geo-statistical analysis by GIS tool was more batter for delineation of any particular water quality parameter (like EC, pH, TDS, RSC and SAR etc.).
Table 3. Nugget, sill and range values for the average values of the archive data set (time period 2007).

\begin{tabular}{lcc}
\hline Parameters & Unit & $\mathrm{F}^{-}(\mathrm{mg} / \mathrm{l})$ \\
\hline Nugget & (Unit) 2 & -0.9 \\
Sill & (Unit) 2 & 0.18 \\
Range & $\mathrm{m}$ & 19900 \\
\hline
\end{tabular}

\section{REFERENCES}

Anbazhagan, S. and Nair, A. M. (2004). Geographic information system and groundwater quality mapping in Panvel Basin, Maharashtra, India. Environmental Geology, 45(6): 753 761.

Ahmed, S. (2002). Groundwater monitoring network design: Application of Geostatistics with a few Case studies from a granitic aquifer in a semiarid region. In: Groundwater Hydrology (eds. Sherif, M.M., V.P. Singh., M. Al-Rashed). Balkema, Tokyo, Japan, 2: 37-57.

APHA (1996). Standard methods for examination of water and waste water 19th eds. Washington, DC.

Barca, E. and Passarella, G. (2008). Spatial evaluation of the risk of groundwater quality degradation. A comparison between disjunctive kriging and geostatistical simulation. Environmental M onitoring and Assessment. 137: 261-273. BIS (1991). Indian standard drinking water - specification (First Revision) IS-10500:1991. BIS, New Delhi, India

Dhiman S.D.and Keshari, A K. (2001).Genesis of fluoride contamination in Western Indian aquifers. In: Proc. Int. conf. on future groundwater resources at risk, FGR 01, June 2527, Lisbon, Portugal, Themes 1-3, 1-8.

Dagostino, V., Greene, E.A., Passarella G. and Vurro, M. (1998). Spatial and temporal study of nitrate concentration in groundwater by means of coregionalization. Environmental Geology, 36: 285-295.

Ekhtesasi, M.R, (2004). Morphometric and morphodynamic study of wind erosion facies of Yazd-Ardakan plain and 
determination of indicator of this process for function in desertification evalution models, Ph.D Thesis, University of Tehran, Faculity of Natural Resources.

Franco, M., Francisca, M.E. and Carro Perez. (2009). Assessment of natural arsenic in groundwater in Cordoba Province, Argentina. Environ Geochem Health, 31: 673682.

Fordyce, F.M. (2007). A health risk assessment for fluoride in Central Europe. Envir onmental G eochemistry and H ealth, 29:83-102.

Finke, P.A., Brus,D.J., Bierkens,M.F.P., Hoogland,T., Knotters, M. and Vries, F. de. (2004). Mapping groundwater dynamics using multiple sources of exhaustive high resolution data. Geoderma, 123: 23-39.

Goovaerts, P., AvRuskin, G., Meiliker, J., Slotnick, M., Jacquez, G. and Nriagu, J. (2005). Geostatistical modeling of the spatial variability of arsenic in groundwater of southeast Michigan. J ournal of Water Resources, 41: 1-19,

Gaus, I., Kinniburgh, D.G., Talbot J.C. and Webster, R. (2003). Geostatistical analysis of arsenic concentration in groundwater in Bangladesh using disjunctive kriging. Environmental G eology, 44: 939-948.

Goovaerts, P. (1999). Geostatistics in soil science: State-ofthe-art and perspectives. Geoderma, 89:1-45

Goovaerts, P. (1997), Geostatistics for natural resource evaluation. Oxford Univ. Press, New York

Hong, I. A. and Chon, H. T. (1999). Assessment of groundwater contamination using geographic information systems E nvironmental G eochemistry and Health, 21(3): 273-289.

Hounslow, A.W. (1995). Water quality data analysis and interpretation, Oklahoma State University of Stillwater, Oklahoma, Lewis Publishers. PP-39

Hem, J.D. (1989). Study and interpretation of the chemical characteristics of natural water, (Third Edition), U.S Geological Survey Water-Supply Paper 22:54, United States Government Printing Office 1989.

Handa, B. K. (1975). Geochemistry and genesis of fluoridecontaining ground waters in India. Ground Water, 13 (3) : $275-281$.

Handa, B. K. (1988). Fluoride occurrence in natural waters in India and its significance. B hu-J al News. 3 (2): 31-37.

Istok, J.D. and Cooper, R.M. (1998). Geostatistics Applied to Groundwater Pollution. III: Global Estimates. J ournal of Environmental Engineering, 114 (4): 915-928.
Karthikeyan, G. and Shunmugasundarraj, A. (2000). Research Report. Fluoride, 33: 121-127.

Karro, E., Indermitte, E., Saava, A., Haamer, K. and Marandi, A. (2006). Fluoride occurrence in publicly supplied drinking water in Estonia. E nvironmental G eology, 50(3): 389-396.

Nazari, Zade, F., Arshadiyan Behnaz F. Z. and Vakily Kamran (2006). Study of spatial variability of groundwater quality of Balarood plain in Khuzestan province. The first congress of optimized exploitation from water source of Karoon and Zayanderood Plain. University of Shahre kord, Persian Version, pp: 1236-1240.

Nawlakhe, W. G. and Bulusu, K. R. (1989).Water treatment technology for removal of excess fluoride. Proc. Int. workshop on appropriate methodologies for development and management of ground resources in developing countries, (Hyderabad, India, 2 February- 4 March) 4 (2), 815-828.

Meer, F. Vander. (1993). Introduction to geostatistics (GOL 38) Lecture Note, ITC MSc environmental systems Analysis and monitoring module, ESM.

Robinson, T. P. and Metternicht, G. (2006). Testing the performance of spatial interpolation techniques for mapping soil properties. Computer and Electronics in Agriculture, 50: 97-108.

Stefanoni, L.H. and Hernandez, R.P. (2006). Mapping the spatial variability of plant diversity in a tropical forest: Comparison of spatial interpolation methods. Environmental M onitoring and Assessment, 117: 307-334.

Safari, M. (2002). Determination filtration network of Groundwater using geostatistic method. M.Sc Thesis. University of Tarbiyat Modares, Agricultural Faculty, Persian Version.

Srivastava, A., Tripathi, N. K. and Gokhale, K.V. G. K. (1997). Mapping groundwater salinity using IRS-1B LISS II data and GIS techniques. International J ournal of Remote Sensing, 18(13) : 2853-2862.

Sawyer, C. N. and Mcarty, P. L. (1967). Chemistry for sanitary engineers, 2nd edition. New York: McGraw-Hill Education.

Todd, D.K., (1980). Groundwater hydrology. John Wiley and Sons, New York. Microbial Community Fingerprinting at a Waste Disposal Site, pp: 1-11.

WHO (1993). Guidelines for drinkingwater quality, World Health Organization. 